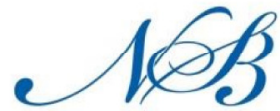

Notulae Scientia Biologicae

Original Article

\title{
Foliar Epidermal Traits of Invasive and Non-Invasive Species of Dracaena Vand. ex L. (Dracaenaceae) in Obafemi Awolowo University Campus, Ile-Ife, Nigeria
}

\section{Abayomi Ezekiel FOLORUNSO*, Omotayo Christianah ADIFAGBADE}

\author{
Obafemi Awolowo University, Department of Botany, Ile-Ife, Osun State, \\ Nigeria;afolorun@oaniffe.edunng(*orrespondingauthor)
}

\begin{abstract}
A comparative foliar anatomical study of the invasive and non-invasive species of Dracaena in Obafemi Awolowo University Campus in Nigeria was carried out. A specific aim of the study was to determine the foliar and morphological traits in Dracaena mannii, which may be responsible for its invasive habit. The foliar anatomical traits were also used to describe the two studied Dracaena species. Fresh and matured leaves of D. mannii and D. arborea were collected and authenticated at the Herbarium of Obafemi Awolowo University (IFE). Quantitative and qualitative data were recorded for morphological traits, whereas scraping techniques were used to obtain the epidermal peels and photomicrographs of slides were taken for observing the anatomical traits. The presence of club-like glandular unicellular trichomes and papillose, high stomata index and frequency of epidermal cells per unit area strengthen the invasive habit of Dracaena mannii. The thin walls of the epidermal cells increase the intercellular flow of assimilates within $D$. mannii, which is also a notable invasive character.
\end{abstract}

Keywords: anatomy, Dracaena, invasive plant, leaf, stomata

\section{Introduction}

Dracaena Vand. Ex L. belongs to the family Draceanaceae, which is represented in East Africa by three genera: Dracaena Vand. Ex. L., Eriospermum Willd. and Sansevieria Thunb. (APG II, 2003). Genus Dracaena consists of 38 species widespread in tropical Africa, from sea level to mountain belt. There are 15 species of Dracaena in Nigeria as reported by The Flora of West Tropical (Hutchinson and Dalziel, 1968). They comprise herbs, shrubs and trees, some with very specialized habitat requirements. Dracaena is an important component of both tropical lowland and mountain forest in Africa. It frequently forms dense stands and may locally dominate the vegetation. Dracaena mannii Baker is a tree with branches terminating in rosettes of relatively short (up to $40 \mathrm{~cm}$ ) and narrow (up to $2 \mathrm{~cm}$ ) leaves. The plant has white, papery, smooth bark, marked with leaf scars. Leaves grow up to $16-40 \mathrm{~cm}$ in length and $1-2 \mathrm{~cm}$ in width. They are relatively small and thin for the genus, thus helping to distinguish this Dracaena species from others in the region (Palgrave and Palgrave, 2002). Dracaena arborea (Willd.) Link is a small tree (high up to $20 \mathrm{~m}$ ) living predominantly in the forest, with its main distribution area in Liberia. The tree is slightly branched, slash green, wood soft and very fibrous. The leaves are simple, alternate, parallel nerved and concentrated at the end of the stems, with a length up to $100 \mathrm{~cm}$.
The fragrant flowers and fleshy berries of some species are edible by animals. The Dracaena family makes up an important group of plants used for interior decoration, to make "green" homes, offices, malls, apartments and decorate different landscape around the world. Some shrubby species such as $D$. deremensis, $D$. fragrans, $D$. godseffiana, D. marginata and $D$. braunii are popular as house plants.

The invasive, non - native, alien, exotic, so called nonindigenous or introduced species are those that evolved elsewhere and have been purposely or accidentally relocated (Folorunso and Awosode, 2013). In general, invasive plants are highly adaptable to a broad range of environmental parameters. The adaptability of varying types of substrate, level of moisture, quality of light and temperature regimes allow them to invade different ecosystems and habitat types. They are highly adapted as for producing an abundance of seeds that, in some cases, may have a long life in the soil seed banks (Muoghalu and Chuba, 2005). Invasive plants can severely damage the ecosystems' health and are being recognized among the major threats for global biodiversity conservation and a significant component of the human induced environmental change (Bradley et al., 2012). Invasive plants are capable of displacing other plants in their habitats. A lot of suggestions have been reported on ways of controlling invasive plant species; some of these measures have been put into practice, but even so, the invasive species kept on multiplying in some cases (Folorunso and Awosode, 2013). 
Dracaena mannii in the forest behind Botany Department in Obafemi Awolowo University began to manifest the characteristics of an invasive plant. Only one individual of the parent $D$. mannii was initially found in the forest, thus this parent plant profusely reproduced itself while displacing other plant species in the forest. As a result of its habit, many stands of Dracaena species are now profusely growing in the forest.

Morphological traits only were used in the Flora of West Tropical Africa for the description of Dracaena species. This study aimed to compare the foliar anatomical traits of the invasive $D$. mannii with those of the non-invasive $D$. arborea. This is envisaged to give information about the foliar and morphological traits in D. mannii that contribute to its invasive habit. The foliar anatomical traits will also be used for future studies and description of the studied Dracaena species.

\section{Materials and Methods}

Fresh and matured leaves of Dracaena mannii were collected from the forest behind Biological Sciences Building, Obafemi Awolowo University, Ile-Ife, Nigeria ( $7^{\circ}$ $28^{\prime} \mathrm{N}$ to $7^{\circ} 45^{\prime} \mathrm{N}$; $4^{\circ} 30^{\prime} \mathrm{E}$ to $4^{\circ} 34^{\prime} \mathrm{E}$ ), while leaves of Dracaena arborea were collected from the Botanical Garden, along Tonkere Road in Obafemi Awolowo University $\left(7^{\circ} 30^{\prime} \mathrm{N}\right.$ to $7^{0} 35^{\prime} \mathrm{N}$; $4^{\circ} 30^{\prime} \mathrm{E}$ to $4^{\circ} 35^{\prime} \mathrm{E}$ ) (Fig. 1). The specimens were identified in the Herbarium of Obafemi Awolowo University, IFE, Nigeria, and voucher specimens were deposited in the Herbarium.

The following morphological traits were studied: the leaf length and breadth, leaf apex, leaf arrangement, leaf margin and leaf shape. For each of these traits, quantitative and qualitative data from ten samples from each of the species were taken. The average values of the quantitative data were recorded.

The scrape techniques were used for the preparation of the epidermal peels, whereby the required epidermis was obtained by scraping off the unrequired mesophyll. Epidermal peels of both adaxial and abaxial surfaces were made using a sharp blade. All tissues above the required epidermis were scraped off; the leaf material undergoing scrapping was intermittently rinsed with water until the required epidermis was reached. The epidermal surface was placed on a clean glass slide. The epidermal peels were stained in $1 \%$ safranin ' $O$ ' for few minutes, rinsed carefully in water to remove excess stain and mounted in dilute glycerin solution. Ten slides from each of the upper and the lower epidermis were prepared per slide and studied. All mcasurcments werc made at $\mathrm{x} 40$ objective lens using an ocular micrometer.

The stomata index (SI) was also calculated. This is the percentage proportion of the number of stomata to the other epidermal cells present on leaf portion. This was done for both adaxial and abaxial surfaces of the leaves using the formula:

Stomata index $(\mathrm{SI})=\mathrm{S} / \mathrm{E}+\mathrm{S} \times 100 \%$

where: $S=$ number of stomata per unit area; $E=$ Number of epidermal cell in the same unit area.

Measured values were then converted into micrometer by multiplying each of the measurement by the ocular constant regarding the magnification under which they

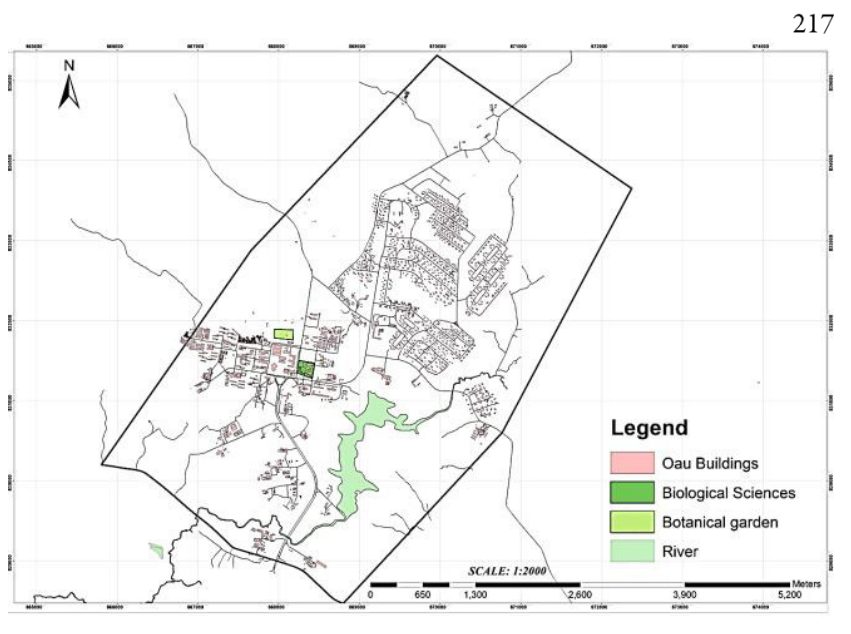

Fig. 1. Map showing the location of Dracaena mannii and Dracaena arborea in Obafemi Awolowo University, Ile-Ife
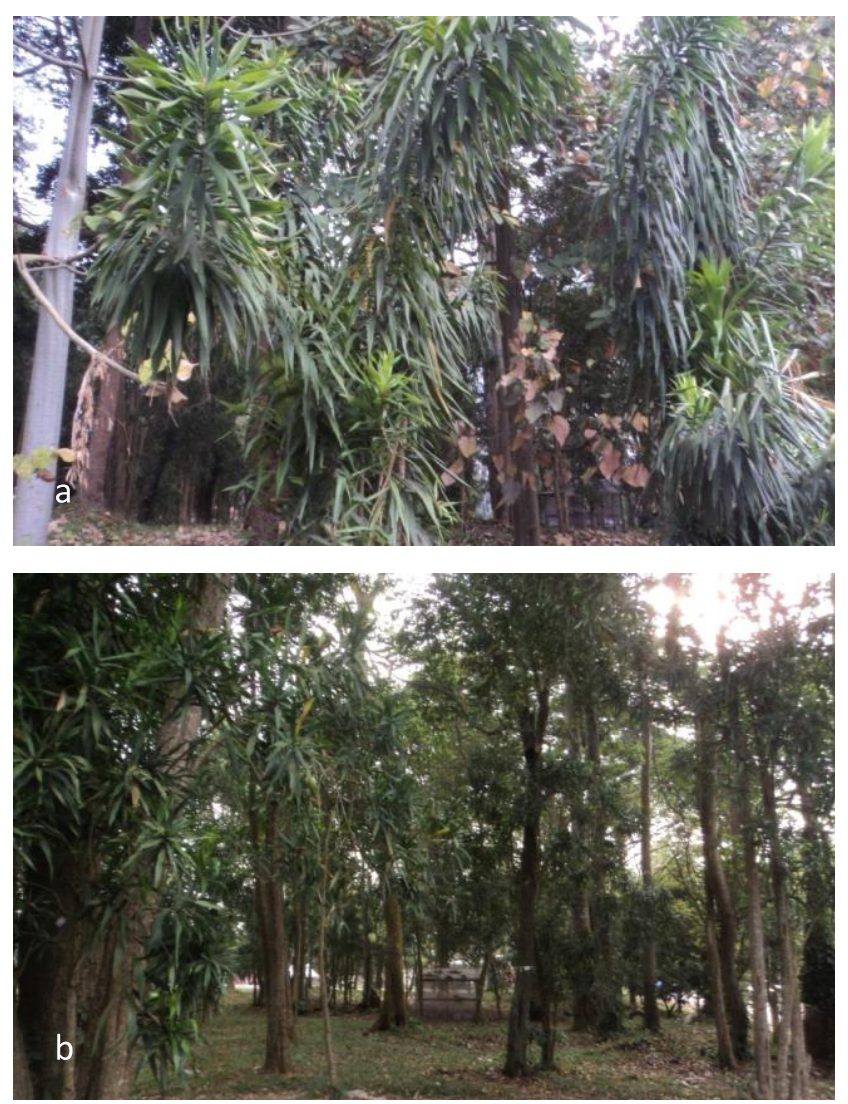

Fig. 2 (a and b). Dracaena mannii, the invasive species in the forest behind Borany Department, Obafemi Awolowo University Campus

were taken. Photomicrographs illustrating the epidermal features were obtained using Amscope MT microscope camera version 3.0001 attached to a light microscope.

Results

\section{Morphological description of Dracaena mannii}

Dracaena mannii is a shrub or small tree which is up to $30 \mathrm{~m}$ tall; the trunk is branched and sometimes stilt-rooted; the inflorescence is terminal and usually branched. The 
218

Table 1. Comparison of adaxial and abaxial anatomical traits of Dracaena mamii and Dracaena arhorea

\begin{tabular}{|c|c|c|c|c|}
\hline \multirow{2}{*}{ Features } & \multicolumn{2}{|c|}{ Dracaena mannii } & \multicolumn{2}{|c|}{ Dracaena arborea } \\
\hline & Adaxial & Abaxial & Adaxial & Abaxial \\
\hline Stomata type & Anomocytic & Anomocytic & Anomocytic & Anomocytic \\
\hline Average stomata length $(\mu \mathrm{m}) \pm S D$ & $2.34 \pm 0.46$ & $3.00 \pm 0.51$ & $2.64 \pm 0.54$ & $2.56 \pm 0.52$ \\
\hline Average stomata width $(\mu \mathrm{m}) \pm S D$ & $1.61 \pm 0.25$ & $1.17 \pm 0.22$ & $2.12 \pm 0.61$ & $1.68 \pm 0.52$ \\
\hline Average stomata frequency per unit area $\pm S D$ & $1 \pm 0.46$ & $7.6 \pm 2.8$ & $2 \pm 1.34$ & $2 \pm 1.34$ \\
\hline Shape of epidermal cells & Regularly elongated & Regularly elongated & Regularly elongated & Regularly elongated \\
\hline Average epidermal cells length $(\mu \mathrm{m}) \pm S D$ & $17.28 \pm 2.75$ & $14.86 \pm 3.80$ & $7.47 \pm 1.38$ & $6.92 \pm 1.62$ \\
\hline Average epidermal cells width $(\mu \mathrm{m}) \pm S D$ & $1.54 \pm 0.22$ & $2.05 \pm 0.44$ & $2.42 \pm 0.62$ & $1.87 \pm 0.48$ \\
\hline Average epidermal cells frequency per unit area $\pm S D$ & $35.7 \pm 3.66$ & $52.6 \pm 12.74$ & $39.9 \pm 6.85$ & $38.3 \pm 8.63$ \\
\hline Stomata index (SI) & 2.80 & 12.62 & 4.77 & 4.96 \\
\hline Trichomes size $(\mu \mathrm{m})$ & 1.3 long, 0.5 wide & 1.5 long, 0.4 wide & Absent & Absent \\
\hline Epidermal cell wall & Thin & Thin & Thick & Thick \\
\hline Tannins & Present & Present & Absent & Absent \\
\hline Average stomata size $(\mu \mathrm{m} \pm S \mathrm{D})$ & $5.39 \pm 1.30$ & $3.27 \pm 1.06$ & $5.68 \pm 2.22$ & $4.56 \pm 2.18$ \\
\hline
\end{tabular}

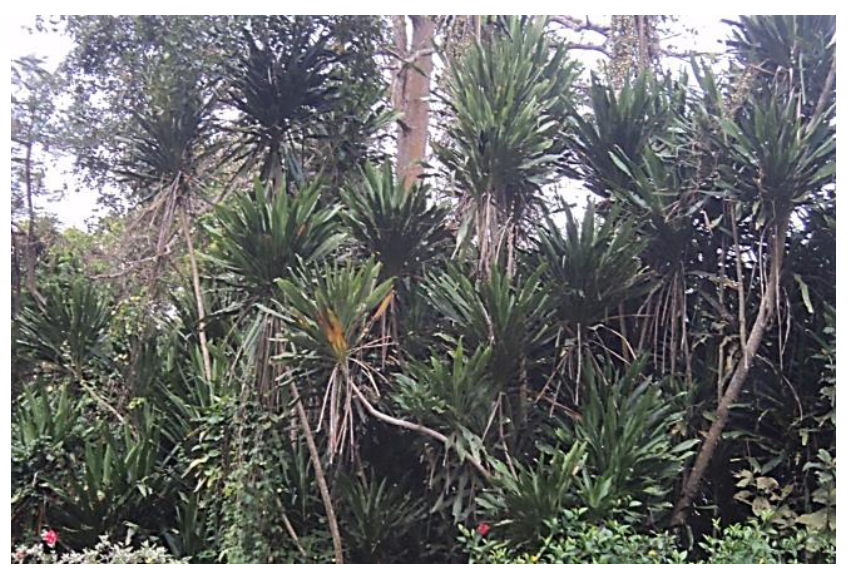

Fig. 3. Dracaena arborea, the non-invasive specics

plant has white, papery, smooth bark, marked with leaf scars (Fig. 2). Based on data obtained by 10 measurements, leaf length ranged from 23.30 to 28.90 $\mathrm{cm}$ (in average $26.36 \mathrm{~cm}$ ), leaf width ranged from 2.20 to $3.00 \mathrm{~cm}(2.63 \mathrm{~cm}$ in average). The leaves were arranged spirally and the leaf margin was straight.

\section{Anatomical description of Dracaena mannii}

Epidermal cells were regularly elongated with straight anticlinal walls. On the adaxial surface, length of epidermal cells size ranged between 9.88 and $20.50 \mu \mathrm{m}$ (in average $17.28 \mu \mathrm{m}$ ), while the width ranged between 1.10 and $1.83 \mu \mathrm{m}$ (in average $1.54 \mu \mathrm{m}$ ) (Table 1). On the abaxial surface, length of epidermal cells was found to be between 8.42 and $23.06 \mu \mathrm{m}$ (in average $14.86 \mu \mathrm{m}$ ) and the width ranged from $1.46 \mu \mathrm{m}$ to $2.93 \mu \mathrm{m}$ (in average $2.05 \mu \mathrm{m}$ ), with straight and thin anticlinal walls. Epidermal cells frequency on the adaxial surface ranged from 29 to 42 (mean of 35.7), whereas epidermal cells frequency on the abaxial surface ranged from 42 to 89 (mean of 52.6).

Stomata fit to the anomocytic type. On the adaxial surface, stomata size ranged from 18.08 to $35.50 \mathrm{um}^{2}$ (in average $5.39 \mu^{2}$ ), with stomata index (SI) of $2.80 \%$ (Table 1). On the abaxial surface, stomata size ranged between 1.61 and $5.34 \mu^{2}$ (in average $3.27 \mu \mathrm{m}^{2}$ ), with SI of $12.62 \%$. The stomata frequency ranged from 0 to $2(1$ in average) on the adaxial surface, while the stomata frequency ranged from 4 to 15 (7.6 in average) on the

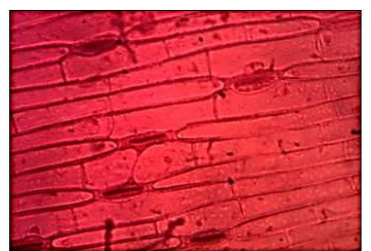

a

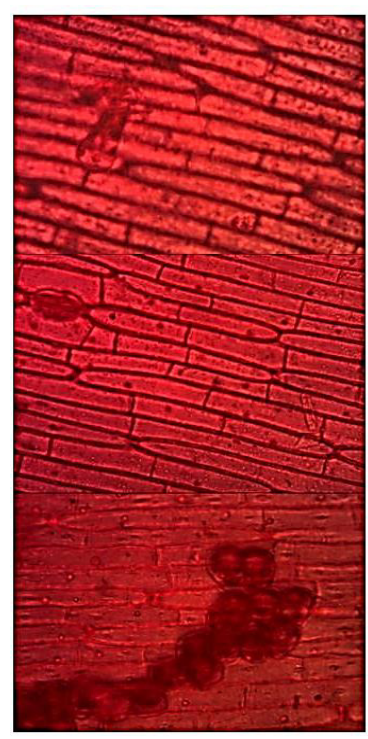

c

Fig. 3. a) Abaxilal surface of $D$. mannii; b) Abaxilal surface of D. arborea; c) $\Lambda$ daxilal surfacc of $D$. mannii; d) $\Lambda$ daxilal surface of $D$. arborea. Scale bar $-1.12 \mu \mathrm{m}$

abaxial surface. Club-like glandular trichomes were present on both sides, with $5.49 \mu \mathrm{m}$ length and $1.46 \mu \mathrm{m}$ idth on the abaxial surface and $4.76 \mu \mathrm{m}$ length and 1.83 $\mu \mathrm{m}$ widthe on the adaxial surface. Ergastic substances like tannins and starch grains were present.

\section{Morphological description of Dracaena arborea}

Dracaena arborea is a small tree predominantly in the forest, with little branches; the height is between 20 and $30 \mathrm{~m}$ and the wood is soft and very fibrous. The leaves are simple, alternate and parallel nerved. The leaf arrangement is whorled, the leaf margin is straight and the inflorescence 
is terminal. Based on data obtained by 10 measurements, leaf length ranged from 62 to $90 \mathrm{~cm}(72.3 \mathrm{~cm}$ in average), while the leaf width ranged from 6.9 to $8.1 \mathrm{~cm}(7.46 \mathrm{~cm}$ in average) (Fig. 3).

\section{Anatomical description of Dracaena arborea}

On the abaxial surface, epidermal cells were regularly elongated with slightly undulate walls ranging between 6.22 and $10.24 \mu \mathrm{m}$ in length (39.9 $\mu \mathrm{m}$ in average) while the width ranged between 1.46 and $3.66 \mu \mathrm{m}(2.42 \mu \mathrm{m}$ average). On the abaxial surface, epidermal cell size ranged between from 3.66 to $9.88 \mu \mathrm{m}$ in length $(6.92 \mu \mathrm{m}$ in average) and the width ranged from 1.10 to $2.56 \mu \mathrm{m}$ (1.87 $\mu \mathrm{m}$ in average). The epidermal frequency ranged between 24 and 49 (with a mean of 39.9) on the adaxial surface and was between 25 and 54 (mean of 38.3) on the abaxial surface. The anticlinal wall was thick and wavy and trichome was absent on both surfaces.

Stomata belong into anomocytic type. On the adaxial surface, stomata size ranged from 2.67 to $10.72 \mu \mathrm{m}^{2}$ (5.68 $\mu \mathrm{m}^{2}$ in average), with stomata index (SI) of $4.77 \%$. On the abaxial surface, stomata size ranged between $2.01-7.50 \mu \mathrm{m}^{2}$ $\left(4.56 \mu \mathrm{m}^{2}\right.$ in average) with SI of $4.96 \%$. The stomata frequency ranged between $0-4$ ( 2 in average) on the adaxial surface, and $0-4$ ( 2 in average) abaxial.

\section{Discussion}

Due to the dominance of Dracaena mannii in the forest behind Botany Department, Obafemi Awolowo University Campus it was supported its classification as an invasive plant, as reported in this study. The traits that strengthen this invasive habit as revealed hereby were the presence of club-like glandular unicellular trichomes, the presence of papillose, high stomata index and frequency of epidermal cells per unit area on the abaxial surface. Foliar anatomical traits had been reported as being responsible for the invasiveness of some taxa (Jayeola, 2000; Folorunso and Awosode, 2013).

Dracaena mannii has thin epidermal cell walls compared to thick epidermal cell walls in Dracaena arborea. While this may be considered as a diagnostic trait to delimit the Dracaena species, it may also be one of the invasive charactcrs of Dracaena mannii. The thin cpidcrmal walls may be a benefit to Dracaena, because it may facilitate intercellular flow of assimilates within the plants. Similar traits, although microscopic (thin leaves), had been used to distinguish by $D$. mannii from other species of Dracaena (Palgrave and Palgrave, 2002).

Trichome in plants is used to control the rate of transpiration, prevent accumulation of toxic salts and reduce the heating effect of sunlight: it also aid in the protection of plant body from outer injurious agents (Peter et al., 1995). Glandular trichomes contain or secrete a mixture of chemicals that have been found to have an enormous array of uses in the pesticide, pharmaceutical and flavor/fragrance industries. Papillae are known to have the function of concentrating the limited light below the canopy of the tropical rainforest by acting as lenses. They also facilitate the removal of water from the leaf surface. However, it must be noted that the invasive species
Draceana mannii may not be used as landmarks because when they start manifesting their invasive attributes, might extend beyond boundary and this may lead to controversy.

\section{Conclusions}

The studied foliar anatomical traits clearly separated the two species (invasive and non-invasive) of Dracaena genus. The presence of club-like glandular trichome, thin epidermal walls and high stomata index were diagnostic traits which can be used to delimit Dracaena mannii from Dracaena arborea. The intergeneric traits reported were the presence of stomata of the anomocytic type and the presence of regularly elongated epidermal cells.

\section{References}

Angiosperm Phylogeny Group (2003). An updare of the Angiosperm Phylogeny Group classification for the orders and families of flowering plants: APG II. Botanical Journal of Linnean Society 141:399-436.

Bradley DT, Bourke TW, Fairley DJ, Borrow R, Shields MD, Young IS, Zipfel PF, Hughes AE (2012). Genetic susceptibility to invasive meningococcal disease: MBL2 structural polymorphisms revisited in a large case-control study and a systematic review. International Journal of Immunogenetics 39(4):328-337.

Folorunso AE, Awosode OD (2013). Compararive anaromy of invasive and non-invasive species in the family Asteraceae in Nigeria. International Journal of Biological and Chemical Sciences 7(5):1804-1819.

Jayeola AA (2000). Comparative ecological anaromy of two aggressive weeds in Nigeria: Tithonia diversifolia (Hemsl.) A. Gray and Chromolaena odvrala (R.H. King and Schrad. Ex DC) H. Robinson. Bulletin of Science Association of Nigerian 23(2000):11-16.

Hurchinson J, Dalziel JM (1968). Phylogenic sequence of orders and families. Flora of West Tropical Africa. Volume 3 Part 1. Crown Agents, London pp 154-159.

Muoghalu JI, Chuba DK (2005). Seed germinarion and reproductive strategies of Tithonia diversifolia and Tilbonia rotundifolia. Applied Ecology and Environmental Research 3(1):39-46.

Palgrave KC, Palgrave MC (2002).Trees of Southern Africa.

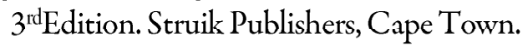

Peter AJ, Shanower TJ, Romeis (1995). The role of plant Trichomes in insects resistance: A selective review. Phytophaga 7:41-64. 